Research Article

\title{
The Evaluation of Physicomechanical and Tribological Properties of Corn Straw Fibre Reinforced Environment-Friendly Friction Composites
}

\author{
Zhen-yu Wang $\mathbb{D}^{1,2}$ Jie Wang $\mathbb{D}^{1},{ }^{1}$ and Yun-hai $\mathrm{Ma}^{3}$ \\ ${ }^{1}$ School of Mechanical Engineering, Sichuan University, Chengdu 610065, China \\ ${ }^{2}$ The Engineering \& Technical College of Chengdu University of Technology, Leshan 614000, China \\ ${ }^{3}$ College of Biological and Agricultural Engineering, Jilin University, Changchun 130022, China
}

Correspondence should be addressed to Jie Wang; wangjie@scu.edu.cn

Received 27 April 2019; Revised 14 July 2019; Accepted 12 August 2019; Published 11 November 2019

Academic Editor: Raffaele Sepe

Copyright $(92019$ Zhen-yu Wang et al. This is an open access article distributed under the Creative Commons Attribution License, which permits unrestricted use, distribution, and reproduction in any medium, provided the original work is properly cited.

Corn stalk fibre reinforced nonasbestos environment-friendly friction composite materials have been fabricated, and their physical, mechanical, and tribological properties are characterized. The tribological properties of the friction composites were evaluated following GB5763-2008 norms on a constant-speed-type friction tester. The experimental outcome reveals that the content of corn stalk fibre has a noteworthy impact on the tribological, mechanical, and physical properties of the friction composites. Specifically, the friction composite with a content of $7 \%$ exhibited excellent friction and wear properties. The worn surface morphology of friction composites was further investigated using a scanning electron microscope. It was found that the corn stalk fibre content greatly affected the tribological properties of the friction composites.

\section{Introduction}

Among brakes, clutches, and driving devices of many vehicles, friction composites make up important parts [1]. The reliability and stability of the executive components are directly linked with friction composites. Hence, suitable friction coefficients and better wear resistance under various temperatures and complex conditions must be presented [2]. The friction composites should be noise-free and vibrationfree in working condition. Moreover, the friction material should not be harmful to human and environment [3]. So they are usually made up of various ingredients, such as resin binder, fibres, abrasive fillers, lubricating or antifriction agent, and quality modifiers $[4,5]$. The influence of each category on the performance parameters of friction material has been extensively discussed and reported in the literature [6-9].

Fibre is an important category because it imparts strength, improves the wear and friction properties of brake composites, and also agitates the drawbacks of inherent composition flaws [10]. Previously, asbestos fibre was selected as the reinforcing component of friction composites, which has been rejected because of its carcinogenicity [3]. In order to find a substitute for asbestos fibre, many researchers have done a lot of research on carbon fibre, ceramic fibre, glass fibre, organic fibre, hemp fibre, and so on [10-15]. In the course of the research, the ideal research results are constantly appearing, and a series of new problems are also generated, such as high cost, unfriendly environment, and unstable hightemperature friction performance [16, 17]. Natural fibres have the advantages of environmental friendliness, low cost, and biodegradability, including bamboo fibres, hemp fibres, banana fibres, jute fibres, and banana fibres, and they are used in friction composites [18-23]. Matějka et al. [24] reported that the effective combination of hazelnut shell and jute fibre can improve remarkably the tribological properties of friction composites. Ma et al. $[25,26]$ studied wool fibre and bamboo fibre reinforced friction composites, respectively. The results illustrated that the friction composite with fibre content of $3 \mathrm{wt} . \%$ had the best wear resistance. Ramesh et al. [27] 
prepared banana fibre reinforced composites and investigated their physical and mechanical properties. Liu et al. [28, 29] investigated the effects of abaca fibre content on the physical, mechanical, and tribological properties of abaca fibre reinforced friction composites. The experimental results revealed that the sample with abaca fibre content of $3 \mathrm{wt} . \%$ had the lowest wear rate. Pozzi and Sepe [30] prepared composites with fibre volume fraction greater than $55 \%$ by hand layup technique. The tensile and flexural properties were analyzed. It was observed that the tensile and flexural strength of silk composites is 1.98 times that of jute composite.

Corn is one of the most widely cultivated plants in the world, while corn stalk fibres are a waste result of corn agriculture [31]. In our previous work, waste tire rubber pellets were successfully utilized in nonasbestos organic brake friction composites [32]. Due to its beneficial attributes such as flexibility, low density, good compatibility, high strength, and toughness, corn stalk fibre finds various applications [33, 34]. Therefore, corn stalk fibre has the potential to be utilized as raw material in brake friction composites. Hence, the current work aims to prepare and assess the tribological, mechanical, and physical properties of the environment-friendly friction composites containing different weight fraction of corn stalk fibres. The tribological properties were studied using a constant-speed-type friction tester following GB/T 5763-2008 standard. Finally, the influence of different weight fractions of corn stalk fibres on the wear mechanism of friction composites was analyzed based on the morphologies of worn surfaces obtained using SEM.

\section{Experimental Detail}

2.1. Preparation and Characterization of Corn Straw Fibres. Corn stalks were harvested from a rural cooperative in Shenyang, China. After being dried naturally for about 20 days, they were crushed and separated into husks, which were then ground into fibres. Prior to use, corn straw fibres were soaked for 24 hours in $3 \% \mathrm{NaOH}$ solution at room temperature to improve the binding strength of fibre-matrix interface $[35,36]$. Thereafter, fibres were washed with distilled water and then dried at $60^{\circ} \mathrm{C}$ for $5 \mathrm{~h}$ in an oven. Finally, the treated fibres were cut to a length of approximately 4$5 \mathrm{~mm}$ and used for friction composite fabrication.

2.2. Preparation of Specimens. The selection of raw materials for friction composites is presented in Table 1. Phenolic resin was used as an adhesive. Paper-based fibre and corn straw fibres were used as reinforcing fibre. Powders such as water slag, purple clay, and shale were used as fillers. Water slag was mainly industrial waste and had good environmental friendliness and economy. In the parent formulation, the phenolic resin content was fixed at 9\%. According to the variable comparison analysis method, the test materials were divided into six groups, which were recorded as FM-0, FM-1, FM-3, FM-5, FM-7, and FM-9, respectively. The content of corn straw fibre increased successively while the proportion of other materials decreased equally. Twelve specimens in each group had been manufactured and tested, and three
TABLE 1: Details of composite designation and composition.

\begin{tabular}{lcccccc}
\hline \multirow{2}{*}{ Raw materials (wt.\%) } & \multicolumn{7}{c}{ Specimens } \\
& FM-0 & FM-1 & FM-3 & FM-5 & FM-7 & FM-9 \\
\hline Corn straw fibres & 0 & 1 & 3 & 5 & 7 & 9 \\
Paper-based fibre & 10 & 9.90 & 9.69 & 9.47 & 9.25 & 9.01 \\
Antiwear powder & 3 & 2.97 & 2.91 & 2.84 & 2.77 & 2.71 \\
Purple sand & 13 & 12.87 & 12.57 & 12.32 & 12.02 & 11.71 \\
Water slag & 11 & 10.81 & 10.52 & 10.31 & 10.12 & 9.91 \\
Vermiculite powder & 7 & 6.93 & 6.78 & 6.63 & 6.47 & 6.31 \\
BaSO $_{4}$ & 25 & 24.75 & 24.21 & 23.58 & 23.02 & 22.52 \\
Shale $_{\text {Brown corundum }}$ & 15 & 14.85 & 14.54 & 14.21 & 13.87 & 13.52 \\
Phenolic resin & 7 & 6.93 & 6.78 & 6.63 & 6.47 & 6.31 \\
\hline
\end{tabular}

parallel tests had been carried out in each experiment to improve the reliability of the data.

The ingredients were weighted with a sensitivity of $10 \mathrm{mg}$ and mixed in a plough type shear mixer (feeder speed $300 \mathrm{rpm}$; chopper speed $3000 \mathrm{rpm}$ ) for $10 \mathrm{~min}$ until a uniform distribution was achieved. In the meantime, a small amount of water was sprayed through the top water inlet during the mixing process to prevent dust from appearing. The mixed material is shown in Figure 1. Because no metal was contained in the mixing materials, these materials were dried using a microwave heating method. Mixed wet materials were placed on the conveyor belt of the equipment, using microwave heating for about $8 \mathrm{~min}$, as shown in Figure 2. Wet mixing and microwave heating methods were used in the mixing process, which was a new approach completely. This approach fundamentally solved the dust pollution problem caused by the traditional dry technology in the mixing process.

Thereafter, the mixture was hot pressed for $10 \mathrm{~min}$ at $155^{\circ} \mathrm{C}$ and $15 \mathrm{MPa}$ in the form of brake pads by using a mould supported by adhesive coated steel plates. During hot pressing, three breathings were allowed to degassing. Then, the brake pads were postcured (to remove residual stresses) in the oven, and process of heat treatment is shown in Figure 3. Prior to the tribological characterizations, the brake pad surfaces were polished with a grinding wheel. Specimens of $25 \mathrm{~mm} \times 25 \mathrm{~mm} \times 6 \mathrm{~mm}$ size were cut from the brake pads and used for tribological testing.

\subsection{Physicomechanical and Tribological Behaviors Evaluation.} The fabricated friction composites were assessed for physical and mechanical properties by following appropriate measuring standard. The hardness of the composites was detected on the Rockwell hardness tester (Model HRSS-150, Shanghai, China) as per the China National Standards (CNS) 2114. According to the JC/T685-1998 friction material density test method, the density of each sample was investigated by using electronic density balance (MP-5002, Shanghai, China) in accordance with the Archimedes method. Impact strength was assessed using an impact testing machine (XJ-40A, Wuxi, China).

The friction and wear performances of the developed friction composites were evaluated on a JF151-type constant-speed friction test machine. The standard regulatory 


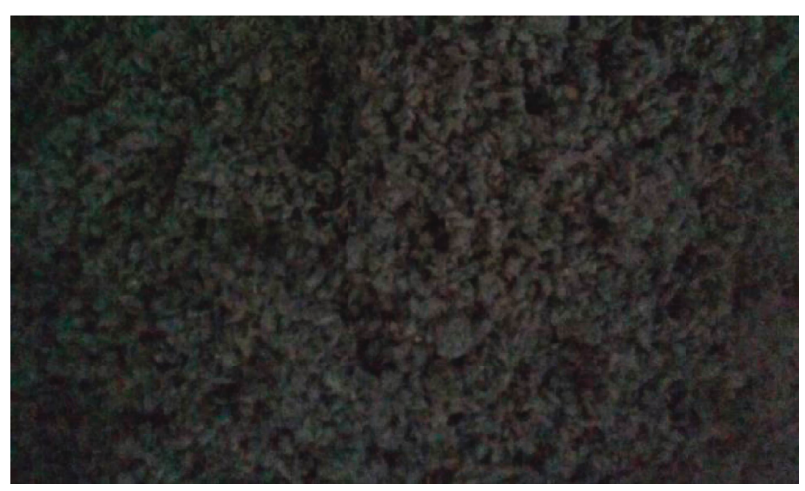

Figure 1: Real photo of the mixed material.

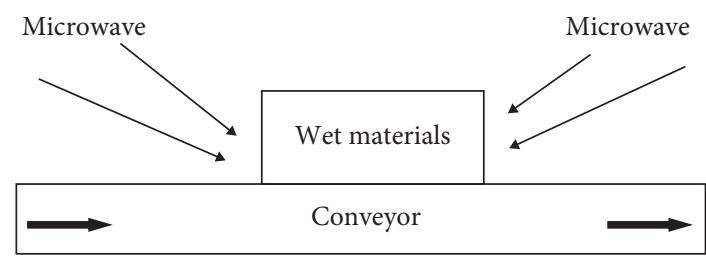

FIgURE 2: Schematic of microwave heating.

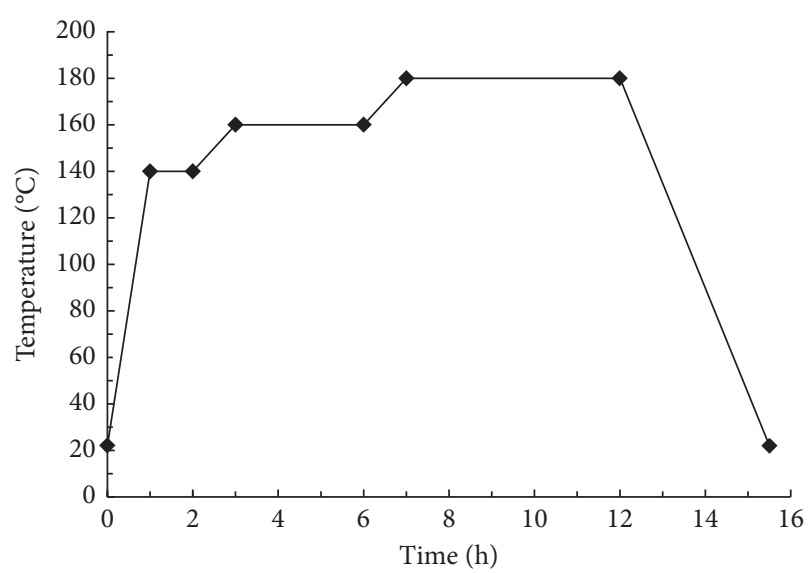

FIGURE 3: Heat-treatment process for preparation of friction composites [28].

test Chinese National Standards GB5763-2008 had been followed for the performance evaluation. The friction-wear mode of the constant-speed friction test machine is indicated in Figure 4, and real photo is shown in Figure 5. A friction cast iron (HT250) disc with a hardness of 180-220 HB rotated at a constant speed of $480 \mathrm{r} / \mathrm{min}$, which temperature was measured by using a temperature sensor. In the middle of the annular surface of the rotating disc, the specimen was applied with a constant positive pressure of $1225 \mathrm{~N}$ through the weight in the vertical direction. During the test, the specimen was continuously dragged on the friction disc and the frictional force was explored by the stretching-compression sensor. The test mainly consisted of two parts, namely the fade test runs and the recovery test runs.

In the fade test runs, the friction disk temperature was set to $100^{\circ} \mathrm{C}, 150^{\circ} \mathrm{C}, 200^{\circ} \mathrm{C}, 250^{\circ} \mathrm{C}, 300^{\circ} \mathrm{C}$, and $350^{\circ} \mathrm{C}$, respectively. In the recovery test runs, the friction disk temperature was set

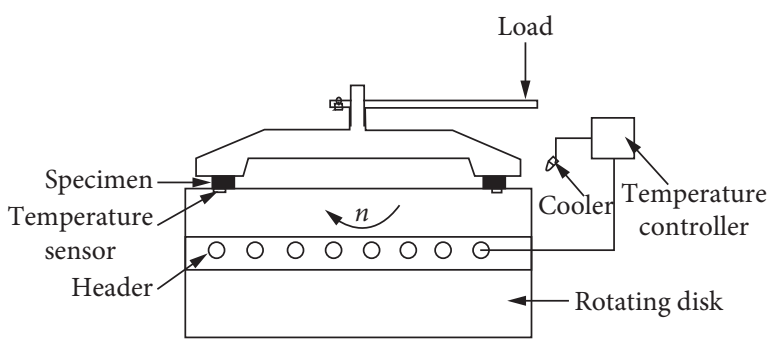

Figure 4: Schematic of the friction-wear mode [28].

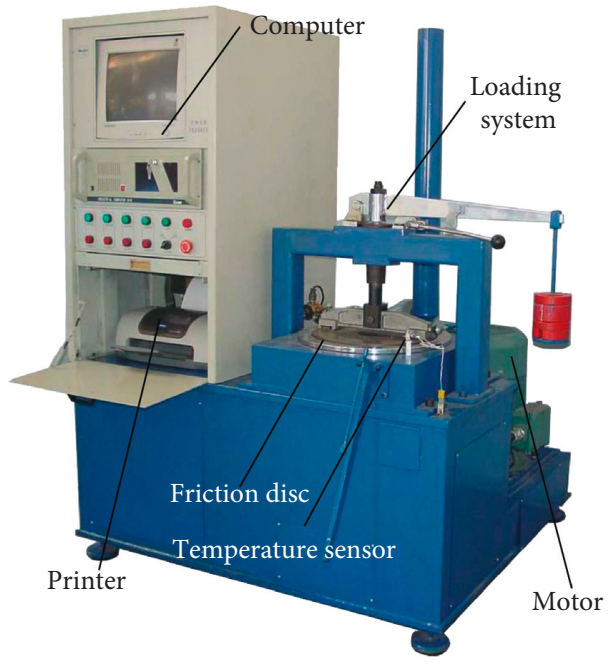

Figure 5: Real photo of the constant-speed tester.

to $300^{\circ} \mathrm{C}, 250^{\circ} \mathrm{C}, 200^{\circ} \mathrm{C}, 150^{\circ} \mathrm{C}$, and $100^{\circ} \mathrm{C}$ in sequence. After the friction disk rotating for $5000 \mathrm{rpm}$, the friction coefficient was recorded separately at different temperatures, and the thickness of the sample under the same temperature condition was measured.

Friction coefficient $(\mu)$ and wear rate $(\Delta W)$ were automatically calculated through the computer software. Wear rate $(\Delta W)$ was determined as follows [28, 37]:

$$
\Delta W=1.06 \times \frac{A\left(d_{1}-d_{2}\right)}{N \cdot f_{m}},
$$

where $A$ is the specimen friction area $\left(A=625 \mathrm{~mm}^{2}\right) ; d_{1}$ and $d_{2}$ are the average thickness of specimens before and after tests $(\mathrm{cm})$, respectively; $N$ is the number of revolutions of the friction $\operatorname{disc}(N=5000)$; and $f_{m}$ is the average friction force (N).

\section{Results and Discussion}

3.1. Morphology and Interfacial Characterization of Corn Straw Fibres. Figure 6(a) shows the morphology of the untreated corn stalk fibre. Obviously, the surface of the corn stalk fibre distributed a number of impurity particles, which may be composed of pectin, wax, and lignin. After treatment with $\mathrm{NaOH}$ solution, impurity particles disappeared and many node structures appeared, as shown in Figure 6(b), which was able to enhance the effective combination of fibrematrix interface [38]. 


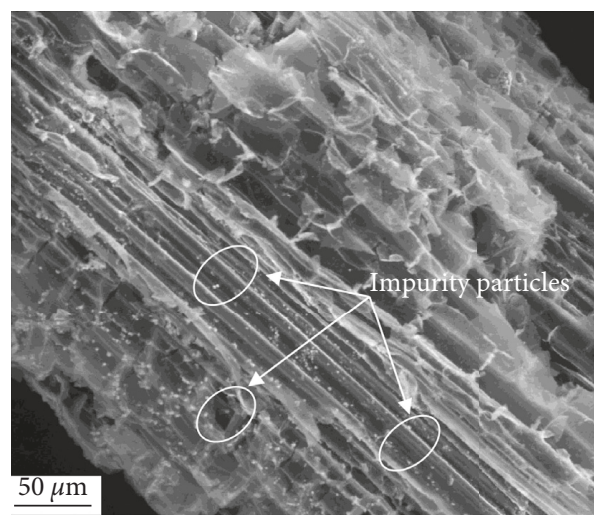

(a)

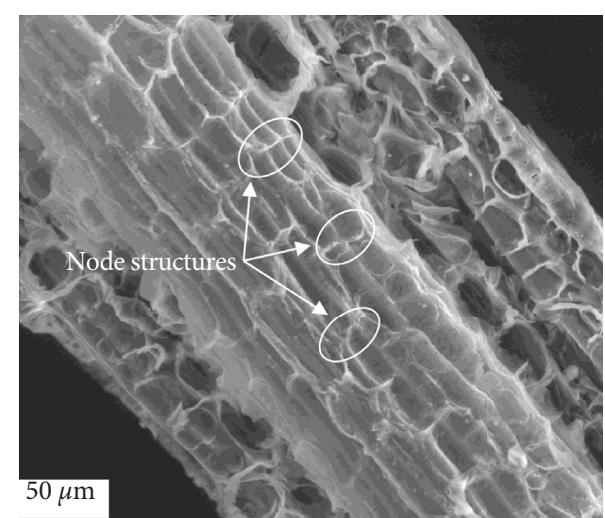

(b)

Figure 6: Morphologies of (a) the untreated corn stalk fibre and (b) the corn stalk fibre treated with $\mathrm{NaOH}$ solution.

3.2. Results of Physicomechanical Characterization. The results of evaluated physical and mechanical properties are arranged in Table 2. As evident from table, the composite FM-0 possesses highest density $\left(2.19 \mathrm{~g} / \mathrm{cm}^{3}\right)$ and hardness (112.4 HRR). The inclusion of increased corn stalk fibre content has contributed to decrease in density and hardness. The decreasing trend in density is expected because of the addition of corn stalk fibre, which is lighter than fillers. However, the increase of corn stalk fibre did not cause obvious variation trend in the value of the impact strength. In conclusion, the addition of a certain amount of corn stalk fibre can improve the physical and mechanical capabilities of composites. This is consistent with the results of the team's previous research [39].

3.3. Tribological Properties of the Composites. The fade and recovery response of six investigated friction composites are illustrated in Figure 7. During the fade test runs, the friction coefficient of all composites increased and then decreased with the increasing of temperature. Meanwhile, the friction composites above $250^{\circ} \mathrm{C}$ exhibited decreasing trend in $\mu$. The main reason for this change was that the phenolic resin in friction composites was a kind of high polymer, which was more sensitive to temperature. With the increasing of test temperature, the internal structure of phenolic resin changed from glass phase to rubber phase, and at the same time, the adhesive force between components enhanced, so the friction coefficient increased. When the temperature exceeded $200^{\circ} \mathrm{C}$, phenolic resin and lignin in corn straw fibres began to decompose, and fibres were gradually carbonized in the meantime [24]. Therefore, the friction surface film was formed with a certain lubricating function, and dry friction was converted into mixed friction or fluid friction, resulting in a significant decrease trend in the friction coefficient [40]. The friction coefficient of each specimen was higher at 150 and $200^{\circ} \mathrm{C}$, which was approximately equal. The friction coefficient at $100^{\circ} \mathrm{C}, 250^{\circ} \mathrm{C}$, and $300^{\circ} \mathrm{C}$ was slightly lower, while was lowest at $350^{\circ} \mathrm{C}$. Except for the case at $100^{\circ} \mathrm{C}$, the composite FM-7 had a higher friction coefficient than other composites and exhibited excellent friction properties, followed by FM-5 and FM-9. It seemed
TABle 2: Physical and mechanical properties of the friction composites.

\begin{tabular}{lccc}
\hline Specimens & $\begin{array}{c}\text { Density } \\
\left(\mathrm{g} \cdot \mathrm{cm}^{-3}\right)\end{array}$ & $\begin{array}{c}\text { Hardness } \\
(\text { HRR })\end{array}$ & $\begin{array}{c}\text { Impact } \\
\text { strength } \\
(\mathrm{MPa})\end{array}$ \\
\hline FM-0 & 2.19 & 112.4 & $0.241 \pm 0.008$ \\
FM-1 & 2.16 & 109.2 & $0.263 \pm 0.011$ \\
FM-3 & 2.14 & 108.8 & $0.238 \pm 0.006$ \\
FM-5 & 2.09 & 105.6 & $0.252 \pm 0.014$ \\
FM-7 & 2.03 & 104.3 & $0.285 \pm 0.009$ \\
FM-9 & 1.96 & 101.2 & $0.273 \pm 0.015$ \\
\hline
\end{tabular}

that the friction composite with corn straw fibre content of $7 \%$ is most suitable. The composite FM- 0 without corn straw fibres showed a drastic decrease when the temperature exceeded $200^{\circ} \mathrm{C}$. During the recovery test runs, the overall variation trends of all specimens were that the friction coefficients decreased slowly with the change of temperature from $300^{\circ} \mathrm{C}$ to $150^{\circ} \mathrm{C}$, and the friction coefficients increased slowly during the temperature drop from $150^{\circ} \mathrm{C}$ to $100^{\circ} \mathrm{C}$. The main reason for this phenomenon might be that after $350^{\circ} \mathrm{C}$ high temperature, the volatile matter released by the thermal decomposition of organic components (phenolic resin, organic fibre, and straw fibre) had basically completed. In the recovery test at $300^{\circ} \mathrm{C}$, because there was no friction surface film produced by volatiles, the friction surface was relatively rough, so the friction coefficient was relatively high, and then the wear debris increased. Under the action of normal and tangential forces, these wear debris formed a secondary contact platform through the adsorption and accumulation of fibres, which made the rough surface relatively smooth, and the friction coefficient decreases gradually. With the destruction of the secondary contact platform, the friction coefficient increases gradually when the temperature decreases from $150^{\circ} \mathrm{C}$ to $100^{\circ} \mathrm{C}$. In addition to $250^{\circ} \mathrm{C}$, the composite FM- 0 showed the lowest friction coefficient at each test temperature. The variation of the friction coefficient of the composite FM-7 was lowest. In any case, the friction coefficient at every test temperature conformed to the Chinese National Standard.

The average thickness of each specimen before and after the test is shown in Table 3. The wear rate of each specimen was calculated by using equation (1). Figure 8 shows the 


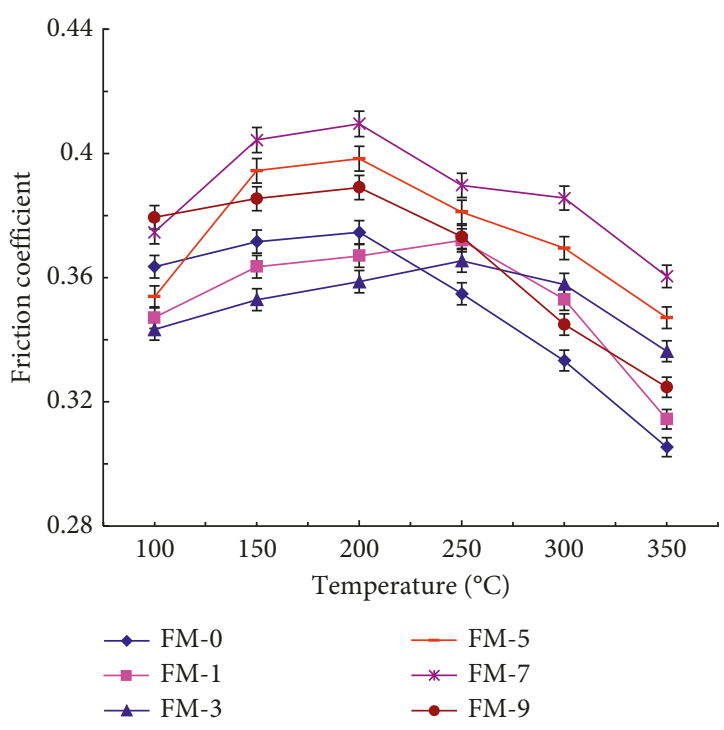

(a)

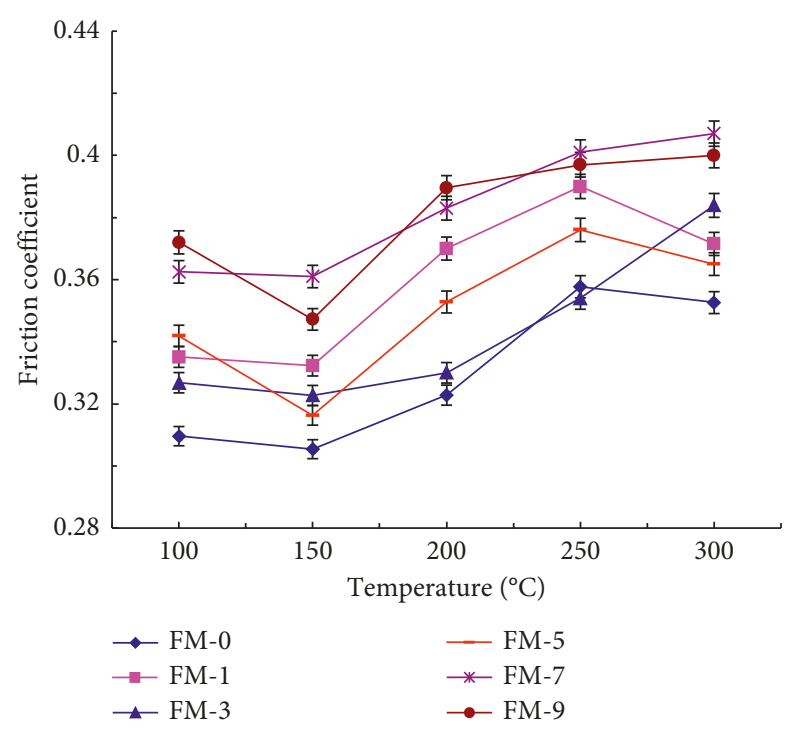

(b)

FIGURE 7: Friction response of the composites: (a) fade test runs and (b) recovery test runs.

TABLE 3: The average thickness of each specimen before and after the test.

\begin{tabular}{|c|c|c|c|c|c|c|c|}
\hline \multirow{2}{*}{ Specimens } & \multirow{2}{*}{ Tests } & \multicolumn{5}{|c|}{ Measuring points $(\mathrm{cm})$} & \multirow{2}{*}{$\begin{array}{c}\text { Average } \\
\text { thickness }(\mathrm{cm})\end{array}$} \\
\hline & & 1 & 2 & 3 & 4 & 5 & \\
\hline \multirow{2}{*}{ FM-0 } & Before & 0.5981 & 0.5962 & 0.6039 & 0.6045 & 0.6038 & 0.6013 \\
\hline & After & 0.5517 & 0.5504 & 0.5578 & 0.5585 & 0.5582 & 0.5553 \\
\hline \multirow{2}{*}{ FM-1 } & Before & 0.6017 & 0.6017 & 0.5992 & 0.6004 & 0.6026 & 0.6011 \\
\hline & After & 0.5482 & 0.5470 & 0.5448 & 0.5456 & 0.5484 & 0.5468 \\
\hline \multirow{2}{*}{ FM-3 } & Before & 0.5989 & 0.5988 & 0.5997 & 0.5992 & 0.6012 & 0.5995 \\
\hline & After & 0.5487 & 0.5472 & 0.5461 & 0.5467 & 0.5486 & 0.5474 \\
\hline \multirow{2}{*}{ FM-5 } & Before & 0.6013 & 0.6012 & 0.6010 & 0.6008 & 0.6013 & 0.6011 \\
\hline & After & 0.5497 & 0.5492 & 0.5486 & 0.5492 & 0.5506 & 0.5495 \\
\hline \multirow{2}{*}{ FM-7 } & Before & 0.5997 & 0.5998 & 0.5995 & 0.5999 & 0.6008 & 0.5999 \\
\hline & After & 0.5528 & 0.5528 & 0.5519 & 0.5524 & 0.5530 & 0.5526 \\
\hline \multirow{2}{*}{ FM-9 } & Before & 0.6001 & 0.5996 & 0.6003 & 0.5997 & 0.6004 & 0.6000 \\
\hline & After & 0.5527 & 0.5522 & 0.5527 & 0.5520 & 0.5526 & 0.5524 \\
\hline
\end{tabular}

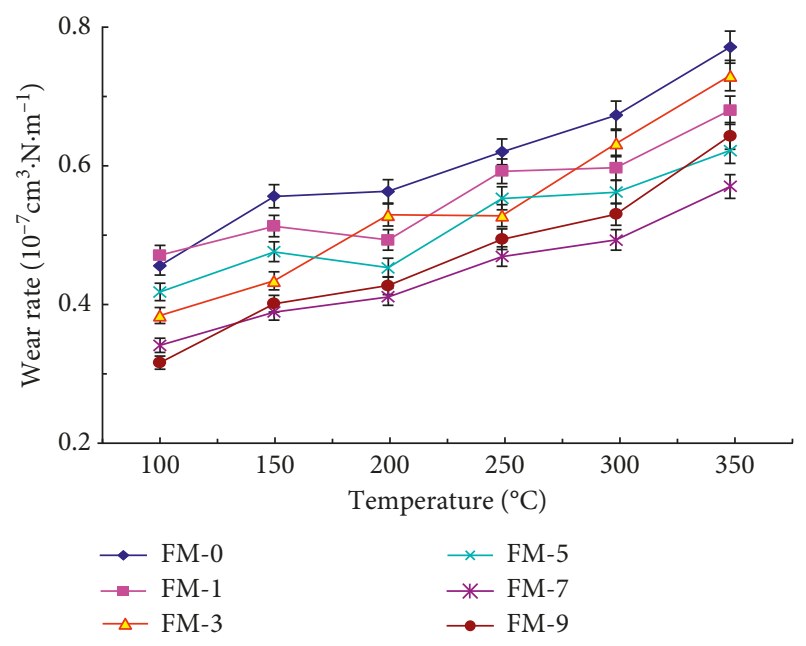

Figure 8: Wear rates of the composites. effect of corn straw fibre on the wear rate of the composites. It is visible from Figure 8 that with the increase in temperature, the wear rate of the composites increased. The specimen FM-0 without corn straw fibres showed the highest wear at each temperature. The main cause of this behavior may be attributed to the lack of fibre bridging between components, resulting in the powder particles being placed in a relatively distributed state. With the increase of temperature, the wear debris increased and fell off, which led to the continuous increase of wear. At high temperature, the thermal decomposition reaction of phenolic resin was aggravated, and the bond strength decreased greatly, which resulted in the decrease of the strength of friction composites and the gradual increase of wear. However, the friction composites containing corn straw fibre could improve its thermal stability and wear resistance due to fibre bridging. The composite FM-7 with $7 \%$ straw fibre content had the lowest wear rate except $100^{\circ} \mathrm{C}$. 
The sum wear rates of the investigated friction composites are presented in Figure 9. One can see that the sum wear rates of friction composites with different fibre contents changed significantly, and the order of change was as follows: FM-0 $>$ FM-1 $>$ FM-3 $>$ FM-5 $>$ FM$9>$ FM-7. This result indicates that with the increase of the content of the corn straw fibre, the sum wear rates of specimens decreased gradually and then increased. The sum wear rates of the composite FM-0 was highest $\left(3.638 \times 10^{-7} \mathrm{~cm}^{3} \cdot(\mathrm{N} \cdot \mathrm{m})^{-1}\right)$ and which of the composite FM-7 was the lowest $\left(2.675 \times 10^{-7} \mathrm{~cm}^{3} \cdot(\mathrm{N} \cdot \mathrm{m})^{-1}\right)$, followed by FM-5 and FM-9. In few words, adding appropriate amount of fibre materials is an effective way to improve the friction and wear properties of friction composites [41].

3.4. Worn Surface Morphology Analysis. Important information on friction and wear can be obtained by observing the wear surface and wear debris of the friction composite. The worn surface morphology of friction composites is an important basis for judging the friction and wear mechanism of friction composites [42]. It was reported in the literature that the formation of contact plateaus on the worn surfaces of friction composites helps in stabilizing the friction and wear performances [12, 43]. The wear surface of the corn straw fibre reinforced friction composites has been investigated by using the scanning electron microscope, and the corresponding worn surface micrographs are presented in Figure 10. The worn surface of the friction composite FM-0 (Figure 10(a), without corn straw fibre) was observed to have an increased amount of loose matrixes, wear debris, and voids formed by the scattered particles. This may be due to the lack of fibre bridging, which greatly weakened the reinforcement, resulting in a lower friction coefficient (Figure 7 ), especially at high temperatures $\left(250^{\circ} \mathrm{C}-350^{\circ} \mathrm{C}\right)$. This may be the reason of the high wear rate of the composite FM-0 (Figure 8) and a significant decreased wear resistance. Comparing with FM-0, the friction composites containing corn straw fibre were relatively compact, which indicated that corn straw fibre could strengthen the interface of friction materials. The worn surface of the friction composite FM-1 (Figure 10(b), 1 wt.\% corn straw fibre content) showed very rough topography with cracks, grooves, voids, spalling pits, wear debris, and particles. This demonstrated that the relative low fibre content could not enhance the bonding strength of the fibre and matrix [28], which corresponded to the relatively high wear rate (Figures 8 and 9). For the case of FM-3 (Figure 10(c), 3 wt.\% corn straw fibre content), the friction composite was slightly damaged, and voids and relatively loose particles were not observed indicating weakened wear in the composites, which provided evidence that the increase in corn straw fibre content had a reinforcing effect on the composites. As shown in Figure 10(f), the worn surface of composite FM-9 (9 wt.\% corn straw fibre content) appeared with many bare fibres and a small amount of secondary plateaus. This illustrated

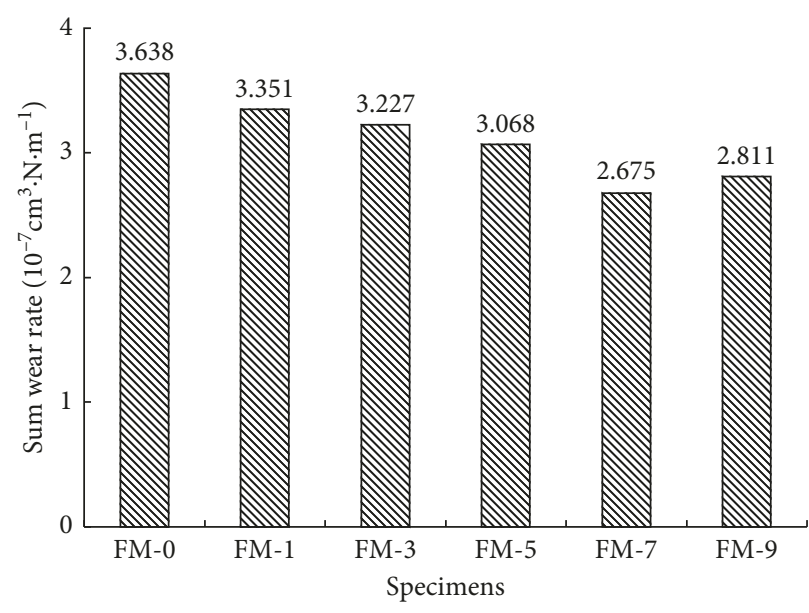

FIgURE 9: The sum wear rates of friction specimens.

that when the straw fibre content increased to $9 \%$, the straw fibre agglomerated, resulting in a decrease in the bond strength between the fibre and the matrix, which weakened the fibre reinforcement effect to some extent. As indicated in Figures 10(d) and 10(e), the worn surface of composites FM-5 (5 wt.\% corn straw fibre content) and FM-7 (7 wt.\% corn straw fibre content) was observed to have a large number of secondary contact plateaus, and the area of the specimen FM-7 was larger than that of the FM-5, which revealed that the core straw fibre content between $5 \%$ and $7 \%$ contributes to the formation of the secondary plateaus. The conformation of secondary contact plateaus played an active effect on the tribological properties of the composites [44], which can stabilize the friction coefficient (Figure 7) and decrease the wear rate (Figures 8 and 9) [28].

\section{Conclusions}

Corn stalk fibre reinforced nonasbestos environmentfriendly friction composites have been fabricated and their physicomechanical and tribological properties are studied. The tribological properties of the developed friction composites have been evaluated on a constantspeed friction test machine following GB5763-2008 standard. The evaluated physicomechanical properties such as density and hardness decreased with the increase in corn stalk fibre content. However, the increase of corn stalk fibre did not cause obvious variation trend in the value of the impact strength. During the fade test runs, the friction coefficient of all composites increased and then decreased with the increasing temperature. Except for the case at $100^{\circ} \mathrm{C}$, the composite FM-7 had a higher friction coefficient than other composites and exhibited excellent friction properties, followed by FM-5 and FM9. During the recovery test runs, the overall variation trends of all specimens were that the friction coefficients decreased slowly with the change of temperature from $300^{\circ} \mathrm{C}$ to $150^{\circ} \mathrm{C}$, and the friction coefficients increased slowly during the temperature drop from $150^{\circ} \mathrm{C}$ to $100^{\circ} \mathrm{C}$. 


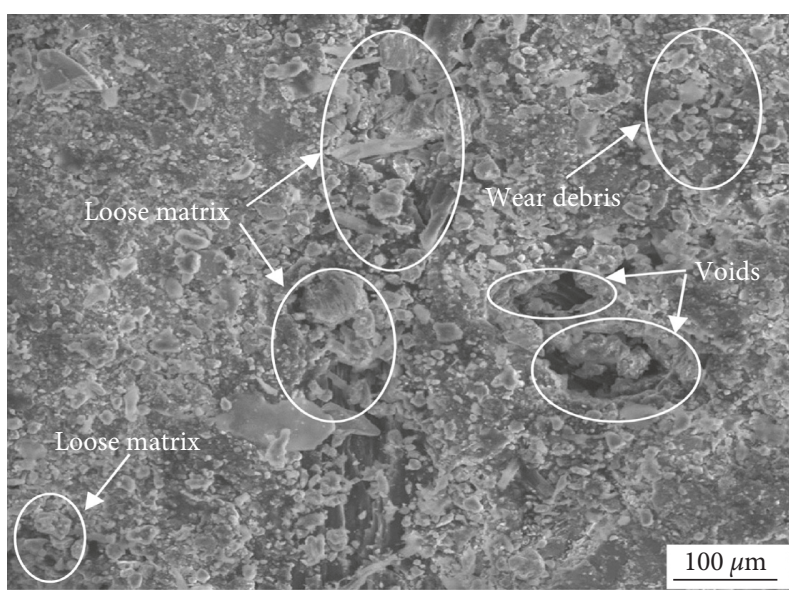

(a)

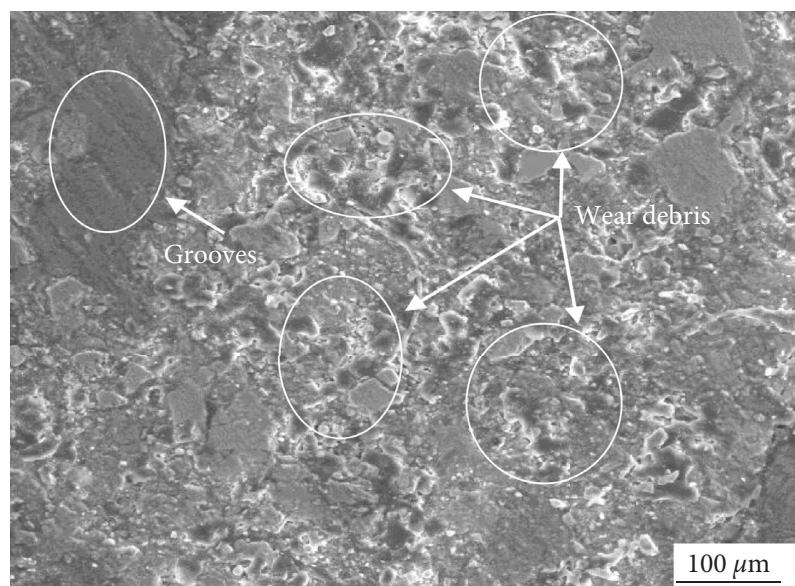

(c)

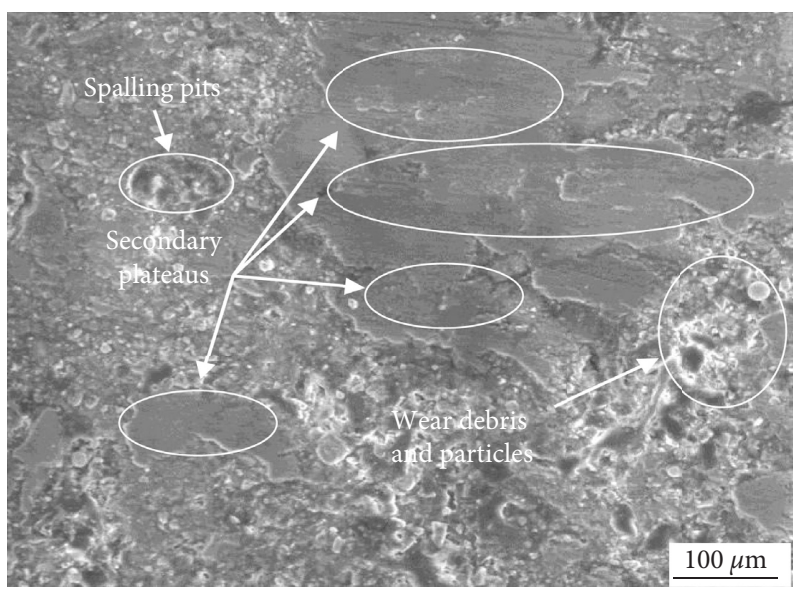

(e)

FIgURE 10: Worn surface micrographs of the composites.

A large number of secondary contact plateaus were presented on the worn surface of the friction composite FM-7 with 7 wt.\% corn stalk fibres, which could enhance wear resistance. According to the experimental outcomes, it can be summarized that a certain amount of corn stalk fibres such as $7 \mathrm{wt} . \%$ proved effective to enhance the

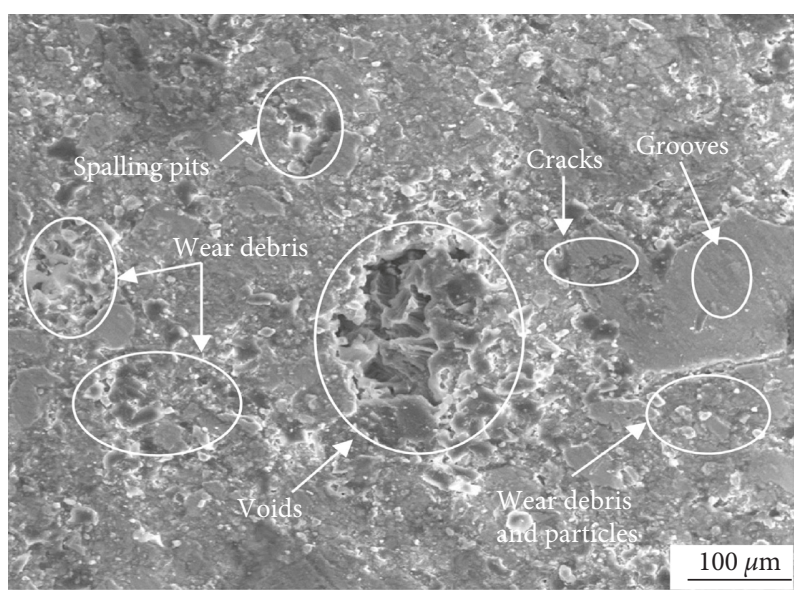

(b)

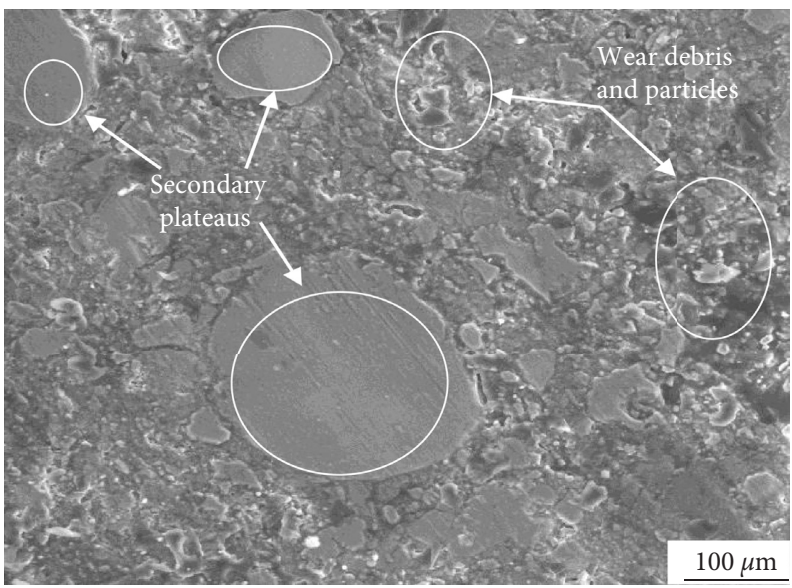

(d)

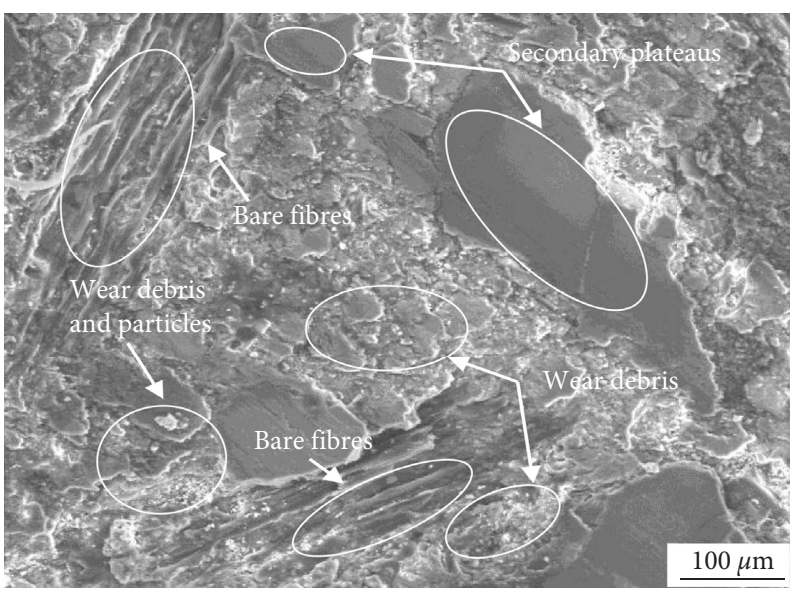

(f)

(a) FM-0. (b) FM-1. (c) FM-3. (d) FM-5. (e) FM-7. (f) FM-9.

friction and wear performance of the composites.

\section{Data Availability}

The data used to support the findings of this study are available from the corresponding author upon request. 


\section{Conflicts of Interest}

The authors declare that they have no conflicts of interest regarding the publication of this paper.

\section{Acknowledgments}

This project was supported by the National Natural Science Foundation of China (Grant no. 51075177) and Jilin Province Science and Technology Development Plan Item (Grant no. 20170101173). Authors thank for the help provided by Jiu Tong Friction Material Co., Ltd., to carry out this work.

\section{Supplementary Materials}

Friction and wear data of the composite FM-0 show the friction coefficient and wear rate of FM-0 at different temperatures during decay and recovery turns. Friction and wear data of the composite FM-1 show the friction coefficient and wear rate of FM-1 at different temperatures during decay and recovery turns. Friction and wear data of the composite FM-3 show the friction coefficient and wear rate of FM-3 at different temperatures during decay and recovery turns. Friction and wear data of the composite FM5 show the friction coefficient and wear rate of FM-5 at different temperatures during decay and recovery turns. Friction and wear data of the composite FM-7 show the friction coefficient and wear rate of FM-7 at different temperatures during decay and recovery turns. Friction and wear data of the composite FM-9 show the friction coefficient and wear rate of FM-9 at different temperatures during decay and recovery turns. Friction test video shows a short video of the friction and wear test process. (Supplementary Materials)

\section{References}

[1] Z. Ji, H. Jin, W. Luo et al., "The effect of crystallinity of potassium titanate whisker on the tribological behavior of NAO friction materials," Tribology International, vol. 107, pp. 213-220, 2017.

[2] M. Kuroe, T. Tsunoda, Y. Kawano, and A. Takahashi, "Application of lignin-modified phenolic resins to brake friction material," Journal of Applied Polymer Science, vol. 129, no. 1, pp. 310-315, 2013.

[3] T. Singh, A. Tiwari, A. Patnaik, R. Chauhan, and S. Ali, "Influence of wollastonite shape and amount on tribo-performance of non-asbestos organic brake friction composites," Wear, vol. 386-387, pp. 157-164, 2017.

[4] V. Matějka, Y. Lu, L. Jiao, L. Huang, G. S. Martynková, and V. Tomášek, "Effects of silicon carbide particle sizes on friction-wear properties of friction composites designed for car brake lining applications," Tribology International, vol. 43, pp. 144-151, 2010.

[5] H. Etemadi, A. Shojaei, and P. Jahanmard, "Effect of alumina nanoparticle on the tribological performance of automotive brake friction materials," Journal of Reinforced Plastics and Composites, vol. 33, no. 2, pp. 166-178, 2014.

[6] J. Bijwe, M. N. Nidhi, and B. K. Satapathy, "Influence of modified phenolic resins on the fade and recovery behavior of friction materials," Wear, vol. 259, no. 7-12, pp. 1068-1078, 2005.

[7] S. J. Kim, M. H. Cho, R. H. Basch, J. W. Fash, and H. Jang, "Tribological properties of polymer composites containing barite $\left(\mathrm{BaSO}_{4}\right)$ or potassium titanate $\left(\mathrm{K}_{2} \mathrm{O} \cdot 6\left(\mathrm{TiO}_{2}\right)\right)$," Tribology Letters, vol. 17, no. 3, pp. 655-661, 2004.

[8] P. Cai, T. Wang, and Q. Wang, "Effect of several solid lubricants on the mechanical and tribological properties of phenolic resin-based composites," Polymer Composites, vol. 36, no. 12, pp. 2203-2211, 2015.

[9] T. Singh and A. Patnaik, "Thermo-mechanical and tribological properties of multi-walled carbon nanotubes filled friction composite materials," Polymer Composites, vol. 38, no. 6, pp. 1183-1193, 2017.

[10] T. Singh and A. Patnaik, "Performance assessment of lapinusaramid based brake pad hybrid phenolic composites in friction braking," Archives of Civil and Mechanical Engineering, vol. 15, no. 1, pp. 151-161, 2015.

[11] M. Kumar and J. Bijwe, "Optimized selection of metallic fillers for best combination of performance properties of friction materials: a comprehensive study," Wear, vol. 303, no. 1-2, pp. 569-583, 2013.

[12] T. Singh, A. Patnaik, R. Chauhan, and A. Rishiraj, “Assessment of braking performance of lapinus-wollastonite fibre reinforced friction composite materials," Journal of King Saud University-Engineering Sciences, vol. 29, no. 2, pp. 183-190, 2017.

[13] Y. Liu, Y. Ma, X. Lv, J. Yu, J. Zhuang, and J. Tong, "Mineral fibre reinforced friction composites: effect of rockwool fibre on mechanical and tribological behaviour," Materials Research Express, vol. 5, no. 9, Article ID 095308, 2018.

[14] A. De Luca and F. Caputo, "A review on analytical failure criteria for composite materials," AIMS Materials Science, vol. 4, no. 5, pp. 1165-1185, 2017.

[15] R. Sepe, F. Bollino, L. Boccarusso, and F. Caputo, "Influence of chemical treatments on mechanical properties of hemp fiber reinforced composites," Composites Part B: Engineering, vol. 133, pp. 210-217, 2018.

[16] B. D. Grag, S. H. Cadle, P. A. Mulawa, P. J. Groblicki, C. Laroo, and G. A. Parr, "Brake wear particulate matter emissions," Environmental Science and Technology, vol. 34, no. 21, pp. 4463-4469, 2000.

[17] Z. Fu, B. Suo, R. Yun et al., "Development of eco-friendly brake friction composites containing flax fibers," Journal of Reinforced Plastics and Composites, vol. 31, no. 10, pp. 681689, 2012.

[18] P. Zakikhani, R. Zahari, and M. T. H. Sultan, "Bamboo fibre extraction and its reinforced polymer composite material," International Journal of Materials and Metallurgical Engineering, vol. 8, no. 4, pp. 315-318, 2014.

[19] M. Mittal and R. Chaudhary, "Biodegradability and mechanical properties of pineapple leaf/coir fiber reinforced hybrid epoxy composites," Materials Research Express, vol. 6, no. 4, Article ID 045301, 2019.

[20] K. Sandeep, V. K. Patel, K. K. S. Mer, G. Fekete, G. Brijesh, and T. Singh, "Influence of woven bast-leaf hybrid fiber on the physico-mechanical and sliding wear performance of epoxy based polymer composites," Materials Research Express, vol. 5, no. 10, Article ID 105705, 2018.

[21] V. A. Prabu, S. T. Kumaran, and M. Uthayakumar, "Performance evaluation of abrasive water jet machining on banana fiber reinforced polyester composite," Journal of Natural Fibers, vol. 14, no. 3, pp. 450-457, 2017. 
[22] T. Singh, B. Gangil, A. Patnaik, S. Kumar, A. Rishiraj, and G. Fekete, "Physico-mechanical, thermal and dynamic mechanical behaviour of natural-synthetic fiber reinforced vinylester based homogenous and functionally graded composites," Materials Research Express, vol. 6, no. 2, Article ID 025704, 2019.

[23] R. Vimal, K. H. H. Subramanian, C. Aswin, V. Logeswaran, and M. Ramesh, "Comparisonal study of succinylation and phthalicylation of jute fibres: study of mechanical properties of modified fibre reinforced epoxy composites," Materials Today: Proceedings, vol. 2, no. 4-5, pp. 2918-2927, 2015.

[24] V. Matějka, Z. Z. Fu, J Kukutschová et al., "Jute fibers and powderized hazelnut shells as natural fillers in non-asbestos organic non-metallic friction composites," Materials and Design, vol. 51, pp. 847-853, 2013.

[25] Y. Ma, Y. Liu, Z. Gao et al., "Effects of wool fibers on tribological behavior of friction materials," Journal of Thermoplastic Composite Materials, vol. 27, no. 7, pp. 867-880, 2014.

[26] Y. Ma, S. Shen, J. Tong, W. Ye, Y. Yang, and J. Zhou, "Effects of bamboo fibers on friction performance of friction materials," Journal of Thermoplastic Composite Materials, vol. 26, no. 6, pp. 845-859, 2012.

[27] M. Ramesh, T. S. A. Atreya, U. S. Aswin, H. Eashwar, and C. Deepa, "Processing and mechanical property evaluation of banana fiber reinforced polymer composites," Procedia Engineering, vol. 97, pp. 563-572, 2014.

[28] Y. Liu, Y. Ma, J. Che, L. Duanmu, J. Zhuang, and J. Tong, "Natural fibre reinforced non-asbestos organic non-metallic friction composites: effect of abaca fibre on mechanical and tribological behaviour," Materials Research Express, vol. 5, no. 5, Article ID 055101, 2018.

[29] Y. Liu, Y. Ma, J. Yu, J. Zhuang, S. Wu, and J. Tong, "Development and characterization of alkali treated abaca fiber reinforced friction composites," Composite Interfaces, vol. 26, no. 1, pp. 67-82, 2019.

[30] A. Pozzi and R. Sepe, "Mechanical properties of woven natural fiber reinforced composites," in Proceedings of the 15th European Conference on Composite Materials ECCM 2012-Composites at Venice, Venice, Italy, June 2012.

[31] G. Wang, C. Chen, J. Li et al., "Molecular composition and size distribution of sugars, sugar-alcohols and carboxylic acids in airborne particles during a severe urban haze event caused by wheat straw burning," Atmospheric Environment, vol. 45, no. 15, pp. 2473-2479, 2011.

[32] T. Singh, M. K. Rathi, A. Patnaik, R. Chauhan, S. Ali, and G. Fekete, "Application of waste tire rubber particles in nonasbestos organic brake friction composite materials," Materials Research Express, vol. 6, no. 3, Article ID 035703, 2018.

[33] S. Harish, D. P. Michael, A. Bensely, D. M. Lal, and A. Rajadurai, "Mechanical property evaluation of natural fiber coir composite," Materials Characterization, vol. 60, no. 1, pp. 44-49, 2009.

[34] F. Ding, "Mechanical properties and degradation characteristics of corn straw fibers/polylactic acid composite materials," Journal of Agricultural Resources and Environment, vol. 35, no. 5, pp. 455-458, 2018.

[35] M. M. Kabir, H. Wang, K. T. Lau, and F. Cardona, "Chemical treatments on plant-based natural fibre reinforced polymer composites: an overview," Composites Part B: Engineering, vol. 43, no. 7, pp. 2883-2892, 2012.

[36] C. Merlini, V. Soldi, and G. M. O. Barra, "Influence of fiber surface treatment and length on physico-chemical properties of short random banana fiber-reinforced castor oil polyurethane composites," Polymer Testing, vol. 30, no. 8, pp. 833-840, 2011.

[37] Y. Ma, Y. Liu, L. Wang, J. Tong, J. Zhuang, and H. Jia, "Performance assessment of hybrid fibers reinforced friction composites under dry sliding conditions," Tribology International, vol. 119, pp. 262-269, 2018.

[38] S. H. Ghaffar, M. Fan, and B. McVicar, "Interfacial properties with bonding and failure mechanisms of wheat straw node and internode," Composites Part A: Applied Science and Manufacturing, vol. 99, pp. 102-112, 2017.

[39] Y. Ma, Y. Liu, W. Shang et al., "Tribological and mechanical properties of pine needle fiber reinforced friction composites under dry sliding conditions," RSC Advances, vol. 4, no. 69, pp. 36777-36783, 2014.

[40] P. C. Okonkwo, G. Kelly, B. F. Rolfe, and M. P. Pereira, "The effect of sliding speed on the wear of steel-tool steel pairs," Tribology International, vol. 97, pp. 218-227, 2016.

[41] L. X. Zhong, S. Y. Fu, X. S. Zhou, and H. Y. Zhan, "Effect of surface microfibrillation of sisal fibre on the mechanical properties of sisal/aramid fibre hybrid composites," Composites Part A: Applied Science and Manufacturing, vol. 42, no. 3, pp. 244-252, 2011.

[42] B. Öztürk and S. Öztürk, "Effects of resin type and fiber length on the mechanical and tribological properties of brake friction materials," Tribology Letters, vol. 42, no. 3, pp. 339-350, 2011.

[43] P. D. Neis, N. F. Ferreira, G. Fekete, L. T. Matozo, and D. Masotti, "Towards a better understanding of the structures existing on the surface of brake pads," Tribology International, vol. 105, pp. 135-147, 2017.

[44] S. H. Kim and H. Jang, "Friction and vibration of brake friction materials reinforced with chopped glass fibers," Tribology Letters, vol. 52, no. 2, pp. 341-349, 2013. 


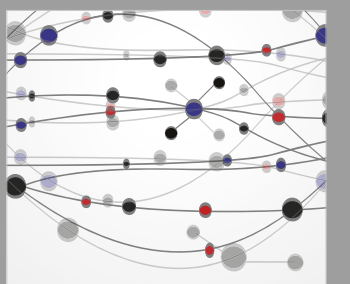

The Scientific World Journal
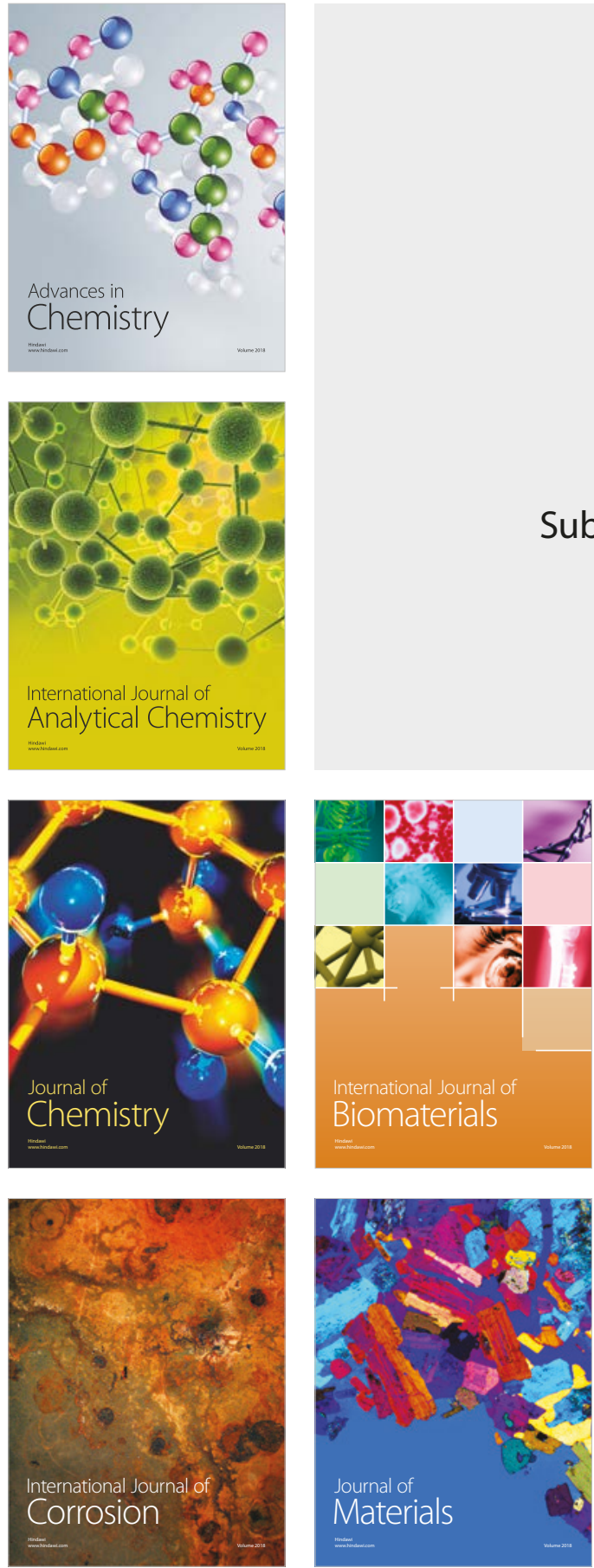

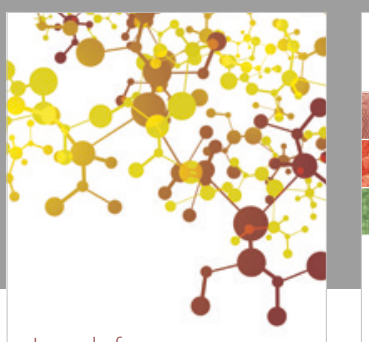

Journal of

Applied Chemistry
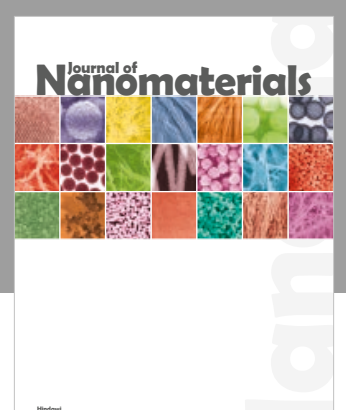

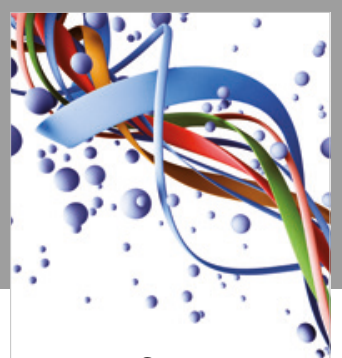

Scientifica

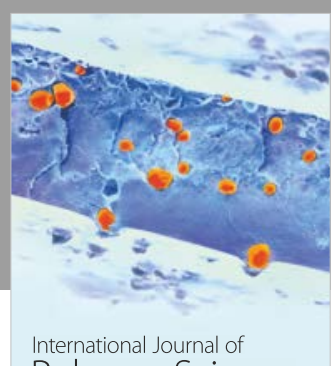

Polymer Science

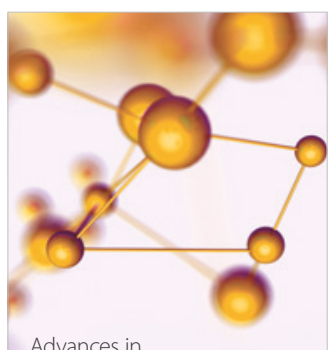

Physical Chemistry
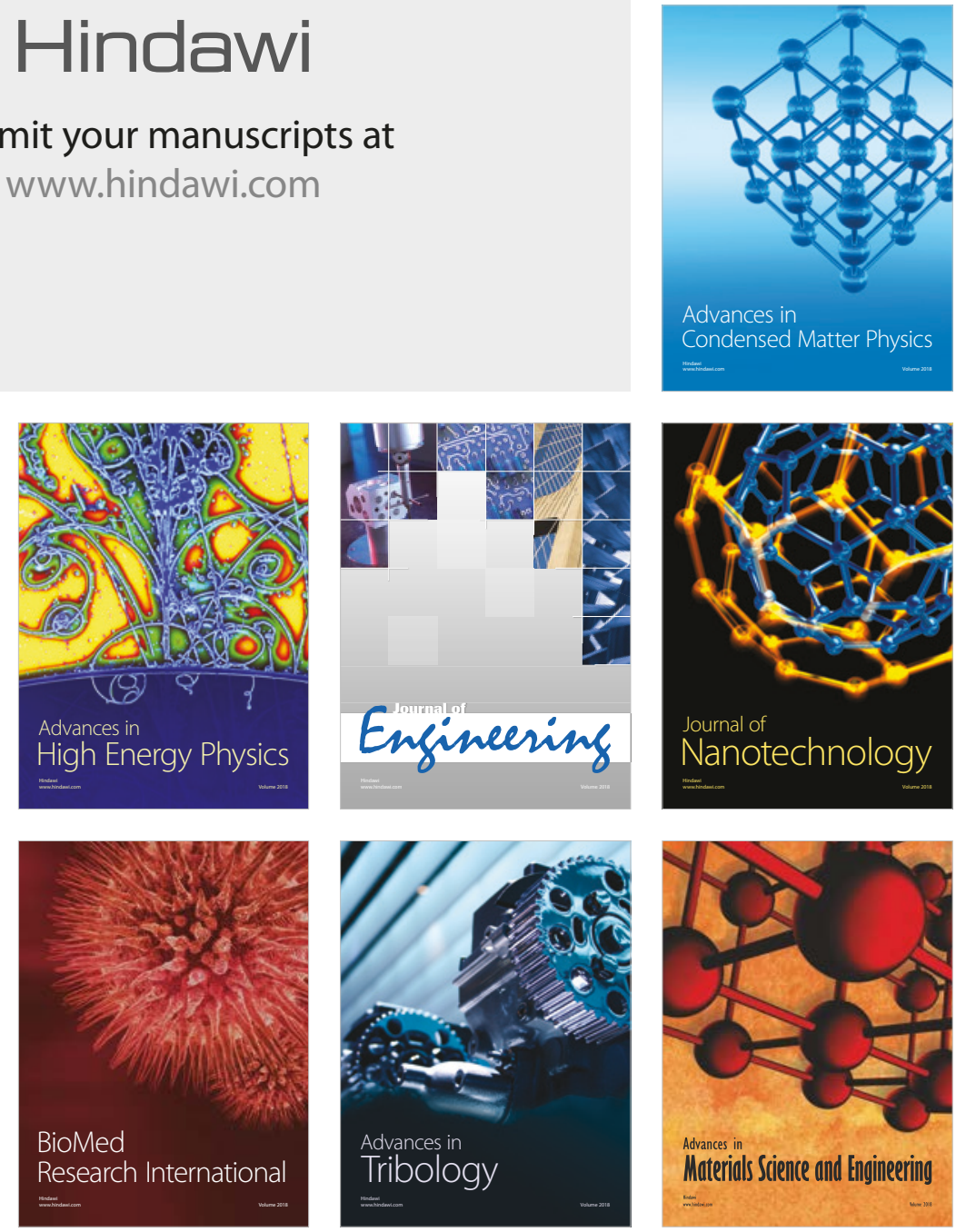